\title{
Approaches to the System Salary Increase in the Region on the Ground of Labor Production Growth
}

\author{
Marina V. Simonova ${ }^{1}$, Lidiya P. Bazhutkina ${ }^{1} \&$ Vladimir A. Berdnikov ${ }^{1}$ \\ ${ }^{1}$ Samara State University of Economics, Samara, Russia \\ Correspondence: Marina V. Simonova, Samara State University of Economics, Sovetskoi Armii Street 141, \\ Samara, 443090, Russia. E-mail: m.simonova@mail.ru
}

Received: December 4, 2014 Accepted: December 30, 2014 Online Published: January 17, 2015

doi:10.5539/res.v7n2p58 URL: http://dx.doi.org/10.5539/res.v7n2p58

\begin{abstract}
In the article current economic task of salary and labor production increase is considered. Drawing on the example of Samara Region as one of stable developing region labor production dynamics is regarded and possibilities for average salary increase as one of the factors of population welfare are analyzed both in the region and in the certain activity fields. Key factors of growth indexes are defined; the necessity for labor production management on the governmental level is emphasized taking into account peculiarities of modern Russian situation. The mutual influence inconsistence of salary and labor production on the production effectiveness is considered. The necessity for research is revealed, which can allow to improve cooperation in the regional economic systems, to define reasons for indexes disbalance, to work out practical recommendations for salary level regulation in the region.
\end{abstract}

Keywords: quality of life, labor production, labor force quality, economic growth, salary, welfare

\section{Introduction}

In the last years Russian economy experiences economic growth rate's slow-up that influences population life quality. Growth rates are different from each other essentially; each region chooses its policy of life quality maintenance and development. Gradual transition of world and Russian economy into the postindustrial phase defines brand-new base of economic growth by means of intellectually-capacious sectors' development (Nilova, 2012). In that context the availability or deficiency of natural resources is one of the factors of innovation development model which should be built on the competent governmental and economic regulation of material, labor and financial resources. The correlation verification of effective labor market development and average salary growth is an urgent economic task (Lentz \& Mortensen, 2008). Drawing on the example of Samara region as one of the stable developing region, tendencies for social-economic development can be considered and possibilities for average salary increase as one of the factors of population welfare can be analyzed both in the region and in certain activity fields.

Elaborated development strategy in the region (Governmental Statistics Federal Agency) makes it possible to orientate on the population welfare growth on account of achieving and advancing average Russian standard of living. Due to the regional development strategy the key targets of real population income's increase can be formulated.

Creating favorable conditions for steady economic development in the Samara region;

Life quality increase of the population of samara region;

Decent wages as a result of labor quality and quantity;

Workforce capacity development and preservation in the Samara region;

Prestige value increase and job placement's attraction in the Samara region.

Target defining allows making out the main task as average salary increase in the region, its realization will stimulate other tasks which are logical continuation of salary increase. Annual system increase of average monthly nominal and real accrued salary is an effective instrument of strategy targets' realization. Labor production and salary's relation is a subject of numerous scientific research using DMP models (Vasburd, 2012; Marianna, 2009; Jeremy \& Valérie, 2011). Together with external influence on labor production which is 
described in the models, labor production data can be used which allow approaching model to the real results and get justified prognostic models. Population welfare and economic activity effectiveness are related factors, the structural balance between them influences economic growth rates.

\section{Theoretical and Methodological Basics}

One of the indexes characterizing life quality is an average salary. This is multifactor index which has diversified practice which is important both for an employee, his family members and for commercial enterprises' activity and for the economy as a whole. Average salary fluctuation is a benchmark showing income dynamics which allows providing required quality life of each citizen (Tyukavkin, 2008). At the same time salary is a key factor of enterprises and organizations activity effectiveness, as it is formed on the base of economic activity's indexes, salary fund formation influences production costs. Macroeconomic indexes have more and more influence on nominal and real salary dynamics (Sorokina, 2013). The research of factors affecting salary increase is a key element of population welfare growth; it can reveal problems and suggest possible growth area.

The regional level of average salary is formed on the base of data of all kinds of activities, territories, levels of positions and qualifications. It makes sense for general tendencies' analysis but it can't reveal details in different directions forming peaks of change. To do this research range of salary and income data is necessary in the fields which characterize each region. Solving regional task of average salary increase should be built on the source structure understanding of salary formation and salary functions. Average salary increase has positive influence on poverty reduction and inequality, demand and stability increase (Cappellari, Dell'Aringa, \& Leonardi, 2012).

As the market relations are formed in our country the role of institutional transformations in the structure of economic relationships is becoming more evident. In the first years after Perestroika the role of intra-productive relationships and connections was determinate, but with the course of time we understand that without strategic institutions, clear and well-thought rules economic activity of the enterprises is limited greatly, and it's impossible to change without relationships system transformation, which is realized through the governmental, social and professional institutions. Salary's fund value at each enterprise is formed considering external and internal factors. Statistics analysis shows that average salary change is closely connected with social guarantees' value in the field of labor cost. It means that except internal factors which influence salary there are a lot of external conditions which affect salary fund at the enterprise and the state can influence this process through the institutional transformations.

State opportunities in the system of values and in the salary increase strategy are quite different and can comprise all range of governmental activity. Without such complex actions exact enterprise's efforts in the field of labor production increase and average salary level can't change the situation considerably. System activity on the base of interrelation organization of business and government in a form of partnership can influence further salary increase.

The main tool of average salary increase is labor production growth. At the same time salary level affects labor production level greatly. Interdependent influence of salary and labor production is researched by many scientists in the past and in modern times (Blanchard \& Diamond, 1989; Simonova, 2014; Beveren, 2012). Research inconsistency reveals problematic character of these issues. Labor production index is not calculated officially for many years in the post Soviet time and it has appeared in the statistics catalogues in the last years. Great changes in the country economy changes social economic relationships essentially, which appear in the process of business activity comprising all fields of activities in the economy. The necessity for scientific ground of happening processes, research which reveal new essence and interrelation of salary and labor production is increasing. New forms of employment, changes in the labor character, market structure, system of governmental and commercial structures' cooperation specifies the necessity for system research of appearing problems and their solutions (Aralbaeva \& Afanasev, 2007). For example at the low salary level with regard to population needs its level is too high in the structure of organization costs (Hagedorn \& Manovskii, 2011). Differences in opinions and approaches to the estimate of different factors show how this issue is urgent and that there is the necessity for the research which can improve relations in the economic systems, reveal reasons for indexes' disbalance, develop practical recommendations to regulate salary level in the region. Dynamics analysis of average salary in Samara region is carried out considering nominal and real salary, the comparison of which will allow estimation not only quantity growth data or salary decrease but also employees' purchasing capacity. Average nominal salary accrued for October 2013 for employees of Samara region is 23956 rubles. Within the month average salary has increased by $3.8 \%$, in comparison with October 2012-by $12.9 \%$. Comparison in dynamics change of nominal and real salary which Samara employees got is shown on the pattern 1. Distinctive peculiarity in the last years has been a considerable growth rates' lag of real population incomes from the growth 
rates of real salary, and there is high volatility of this index (even if there are no seasonal factors' influence). Data in Samara region can be considered exemplary which reflect fluctuation character quite clearly on the federal level. In 2012 surplus of real salary in comparison with the previous year is $108-110 \%$ in different periods, in 2013 surplus to the previous year is $5-106 \%$. The lag is becoming more evident if we compare data with the December 2010. We can see gradual salary decrease when the accrued salary is increasing stably. Such tendency show how ambiguous is the salary increase, when there is formal increase of money supply, population purchasing capacity is decreasing and the effect from the increasing is falling and even can be the opposite. As the main characteristic reflecting actual salary statistic data of average monthly accrued salary are used. One of the drawbacks of this index as statistic characteristic is that in the conditions of the high shadow turnover it doesn't reflect incomes properly.

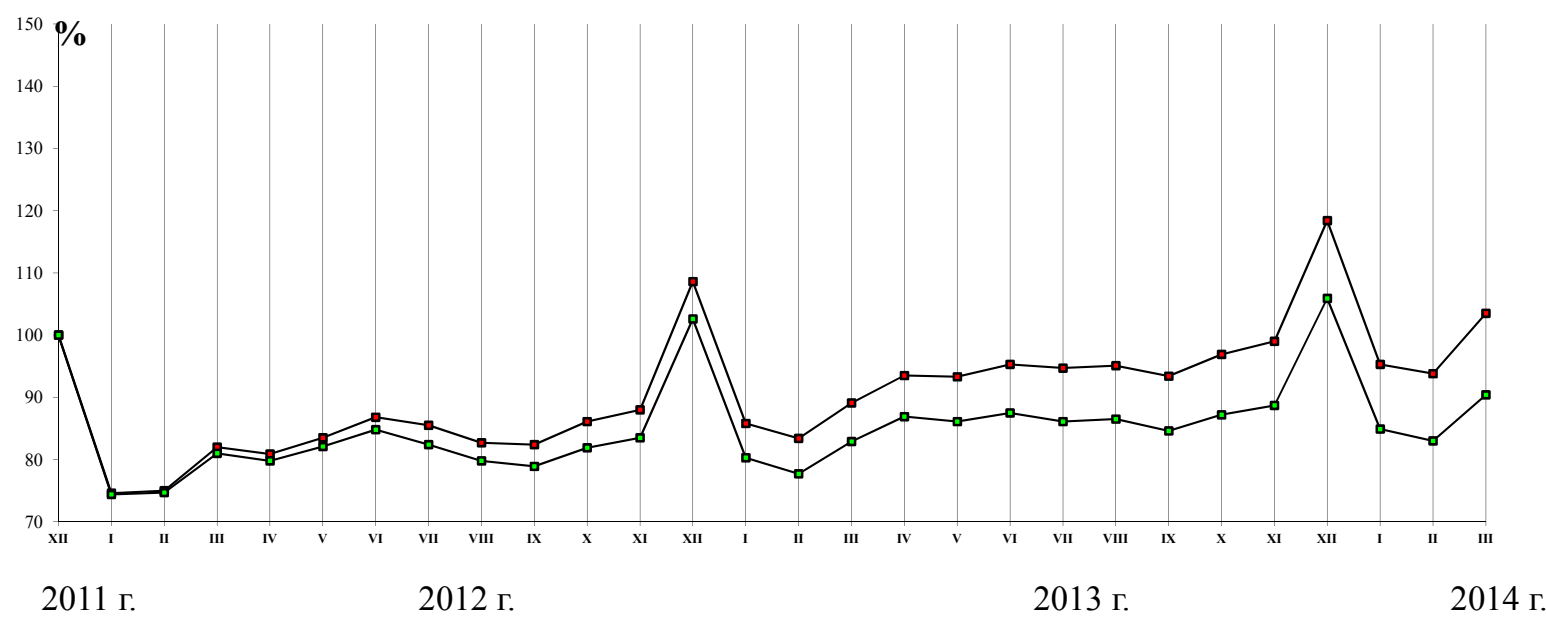

Figure 1. Growth rates (decrease) of nominal and real monthly salary to the employees of Samara region (without social perks) in \% by December 2011 (Simonova, 2014)

Judging by data analysis it's necessary to consider postponing terms of regulated tariffs' indexing at the beginning of 2012 that caused average salary growth in the region and further nominal salary growth in the budget sector which influences average nominal salary. There are other factors which influence nominal and real salary level.

To achieve the goal of increasing population welfare of the region it's necessary to formulate target indicators which will allow feeling confident about the exact figures for gaining at the planned period. Salary increase is a necessary condition for stable region development, life quality increase in the region, and investment attraction increase. To do this it's necessary to achieve exact target indexes, the exact values should be defined after necessary economic ground.

Real population incomes can be introduced in the following indexes:

Average indexes' increase of real salary — by $10-25 \%$ annually and up to 32000 rubles to 2016 ;

Labor production growth - annual indicators' growth by $2-10 \%$;

Gradual regional average salary by the labor categories by $2-10 \%$ a year;

Gradual regional minimal salary increase from $22 \%$ in July 2013 to $35-40 \%$ from the value of average salary by the end of 2014 in the regional economy.

Relation of growth rates of labor production and salary requires a lot of attention as the salary which is not provided with effective labor loses stimulating effect, demotivates activity and disbalances economy. In the last years in the country and in the region there is a tendency of labor production growth rates' slow-up whereas there is growth rates' increase of nominal and real salary (Table 1). Labor production growth indexes in Russian Federation and in Samara region have correlated character in spite of lack of data for some years. 
Table 1. Index dynamics of labor production and salary in Russian Federation and in Samara region

\begin{tabular}{lcccccccccc}
\hline & $\mathbf{2 0 0 3}$ & $\mathbf{2 0 0 4}$ & $\mathbf{2 0 0 5}$ & $\mathbf{2 0 0 6}$ & $\mathbf{2 0 0 7}$ & $\mathbf{2 0 0 8}$ & $\mathbf{2 0 0 9}$ & $\mathbf{2 0 1 0}$ & $\mathbf{2 0 1 1}$ & $\mathbf{2 0 1 2}$ \\
\hline $\begin{array}{l}\text { Labor production } \\
\text { indexes RF }\end{array}$ & 107.0 & 106.5 & 105.5 & 107.5 & 107.5 & 104.8 & 95.9 & 103.2 & 103.8 & 103.1 \\
$\begin{array}{l}\text { Nominal salary index } \\
\text { growth in RF }\end{array}$ & 126.1 & 122.5 & 126.9 & 124.3 & 127.8 & 127.2 & 107.8 & 112.4 & 111.5 & 113.9 \\
$\begin{array}{l}\text { Labor production } \\
\text { indexes in Samara } \\
\text { region }\end{array}$ & - & - & - & - & - & 104.1 & 88.9 & 105.7 & 105.78 & 105.1 \\
$\begin{array}{l}\text { Real salary index } \\
\text { growth in Samara }\end{array}$ & 107.3 & 108.3 & 109.9 & 112.9 & 113.4 & 108.2 & 91.6 & 104.3 & 104.4 & 107.5 \\
$\begin{array}{l}\text { region } \\
\text { Nominal salary index } \\
\text { growth in Samara } \\
\text { region }\end{array}$ & 121.5 & 122.1 & 123.7 & 123.8 & 124.0 & 123.1 & 101.6 & 110.5 & 112.9 & 111.8 \\
\hline
\end{tabular}

Dramatic labor production fall in the crisis of 2008-2009 years up to the present time is not compensated and surplus rates tend to slow up and it doesn't allow achieving before the crisis labor production level. Nominal salary growth rates advance labor production growth rates. Production costs increase, effectiveness falls. At the same time if we compare dynamics of real salary growth and labor production in Samara region we can mark comparable growth indexes.

So money supply increases which is at the population disposal but purchasing capacity and goods flooding are at the same level. Nevertheless population structure by the income level where lower and average-income layers prevail and it allows making a conclusion that there is a necessity for labor production increase by means of salary increase. In Samara region dynamics of coefficients' relation of labor production and employees in the field of economics shows not very positive tendency which has changed to 2011 but it isn't enough to change the whole structure.

Unfortunately, there are no modern data; labor production is calculated in a form of coefficients in relation to the previous year. Among Russian Federation subjects labor production index is calculated by dividing BIP physical volume index into the change index of total labor costs in the equivalent of total employment in the region. Index dynamics on the regional level can be estimated using the following data in the Table 2.

Table 2. Labor production index dynamics in Samara region by the kinds of activities

\begin{tabular}{|c|c|c|c|c|}
\hline \multirow{3}{*}{$\begin{array}{l}\text { Economic } \\
\text { conclusions) }\end{array}$} & & \multicolumn{3}{|c|}{ Labor production } \\
\hline & & \multicolumn{3}{|c|}{ In $\%$ to relation to the previous year } \\
\hline & & 2010 & 2011 & 2012 \\
\hline Total & & 105.70 & 105.78 & 105.1 \\
\hline Agriculture, hunting and forest & A & 71.40 & 173.14 & 111.7 \\
\hline Fishing and fishery & B & 104.69 & 133.30 & 81.1 \\
\hline Mininf & $\mathrm{C}$ & 105.81 & 101.00 & 96.4 \\
\hline Manufacturing & Д & 114.12 & 108.75 & 105.2 \\
\hline $\begin{array}{l}\text { Production and distribution of energy, gas and } \\
\text { water }\end{array}$ & $\mathrm{E}$ & 125.61 & 102.35 & 90.7 \\
\hline Building & $\mathrm{F}$ & 125.32 & 110.76 & 109.4 \\
\hline Wholesale and retail; & G & 98.03 & 102.40 & 101.9 \\
\hline Hotels and restaurants & $\mathrm{H}$ & 96.66 & 97.74 & 101.1 \\
\hline Transportation and connection & I & 102.11 & 102.91 & 106.3 \\
\hline
\end{tabular}




\begin{tabular}{lllll}
\hline Financial activity & $\mathrm{J}$ & 110.76 & 112.85 & 76.6 \\
$\begin{array}{l}\text { Operations with real estate, rent and service } \\
\text { providing }\end{array}$ & $\mathrm{K}$ & 102.34 & 92.84 & 111.3 \\
$\begin{array}{l}\text { Public administration } \\
\text { Education }\end{array}$ & $\mathrm{L}$ & 101.13 & 100.80 & 101.4 \\
Public health service and social services & $\mathrm{M}$ & 98.10 & 96.46 & 99.5 \\
Commercial, social and personal services & $\mathrm{N}$ & 101.22 & 101.51 & 101.8 \\
Household services & $\mathrm{O}$ & 84.82 & 105.28 & 111.8 \\
\hline
\end{tabular}

Using methodology of federal level for labor production calculation all round Russian Federation subjects from a perspective of economic activity is not possible at the moment as on the regional level compatibility of labor costs indexes and production output in economic activities is not provided. Unprejudiced economic data could be got when changing approach to the labor production indexes calculation in physical terms. In this case we can track labor production dynamics not only in relation to the previous year but within the whole period.

- To achieve gradual salary growth there are following areas of activity.

- Essential minimal salary increase on the regional level (MVS);

- Considerable salary increase in the budget field on the regional level;

- Technical reequipment programs to increase effective job places.

Extended reproduction, getting necessary profit and profitability are possible if labor production growth rates advance payment growth rates. Breaking this rule leads to salary fund overdraft, production costs' increase and profit decrease, regional income reduction. Necessary measures are needed both on regional and on enterprise level for seeking additional recourses to increase salary by means of effective work improvement, position structure optimization and progressive norming and salary system introduction (Klimova, 2010).

Taking into account market and non market factors which influence salary level we can make a conclusion that there is a necessity for parity combination of governmental, trade union and private business roles to increase salary. Looking at regional development interests and strategic salary role in region economic development, the governmental role in the institutional field is dominate in the modern situation creating ideological development orients and forming "game rules" despite the prime role of the enterprise in creating labor production and forming salary in stabilizing trade union role.

Difficult process of Soviet economy model restructuring into the market criteria limits production modernization rates and transition to innovative criteria greatly in accordance with gradual engagement into the world economic system which advanced our country by economic development rates. Within the years of reforms Russia lost half of the industrial production volume and hasn't restored it yet. At present time there is a slow up of economic growth rates by $3 \%$ while there are high oil prices. It shows that primary model's recourses are over; there is a necessity for structural economic reconstruction on the base of innovative industrial recovery and human assets development. To the present time there are a lot of industrial enterprises and organizations where technological and organizational culture is on the low level where labor production can't increase so in whole statistics general level falls. Relations of progressive and backward enterprises are not in favorable proportion to the positive dynamics and doesn't allow the country and region to achieve necessary labor production level for massive real salary growth. Essential brake is production logistics underdevelopment, lack of system quality control and technological indiscipline.

Salary fund formation is a result of added value by means of consumer features change of original materials in the labor process. These are classical principles of labor and assets' functioning by means of physical and intellectual labor and thanks to it new items are made the cost of which differs from the original materials' cost forming added value. So profit and salary fund depend on added value which can be obtained by means of labor production increase (Pissarides, 2000). To increase labor production it's necessary to increase added value share in the final product's price. There are possible ways to increase added value.

- labor production increase;

- improvement of product consumer features;

- $\quad$ creating and brand cost increase; 
- creating mechanism of product accompaniment before and after purchasing;

- production process orientation on the client as on actual payer of created added value;

- $\quad$ stimulating demand;

- flexible management, quick reaction to external and internal conditions' change.

Relation of profit value and salary fund volume depends not only on the owner's preferences but also on how government and professional associations influence though the flexible regulation system. Among enumerated ways how to increase added value it's necessary to emphasize labor production as the main mechanism which allow stimulating employees' interest to apply most of their efforts: physical, intellectual, gnostic, ethical and social.

Individual labor production is under influence of necessary and sufficient conditions which are closely connected with each other.

- High personal interest in production process improvement (necessary condition)

- Introduction of scientific labor organization methods together with means of production improvement (sufficient condition).

Labor growth's advancement in comparison with salary growth is necessary to make accumulation providing extended reproduction and development. Logical factor of labor production escalation is economic growth and high-productive or effective job places as demanded products and services can't be produced at out-of-date equipment at low labor organization.

Objective factors of economic growth are:

- Volume and quality capital structure increase;

- Production technologies' change. It is carried out under the influence of scientific and technical progress and is connected with national economy's achievement of high quality growth and development rates;

- Volumes' increase which are involved into economic recourse activity and their application;

- Entrepreneurship activity increase;

- Labor recourses quality and quantity increase;

- Demand activation which allows expanding production volumes for its accomplishment.

Analysis of these factors shows that economic growth, labor production, and population welfare depend on each other and connection of governmental economic policy and effective activity of market subjects. Labor production is under the influence of internal processes in the organization that's why it's necessary to define influence lines of governments and organizations.

- Priorities in the regional authorities to provide high labor production in the region should be the following:

- Internal competition and regional manufactures' support in the conditions of WTO's entrance

- Strategic development integration economic plans and territory planning;

- Stimulation and system support of labor recourses' professional, territorial mobility in accordance with economic situation;

- Dynamic demographic and migration politics, tendencies for quality and quantity indexes' increase of regional labor recourses;

- Regional financial system regulation in terms of local manufacturers' development especially high-technology businesses;

- Formation and development of professional education and employers' interaction on the mutually advantageous basis.

- Areas of business to labor production increase:

- Internal competition development and local manufacturers' support in the conditions of WTO's entrance.

- Strategic development integration economic plans and territory development;

- Stimulation and system support of labor recourses' professional, territory mobility in accordance with economic situation;

- Active demographic and migration policy focusing on quality and quantity indexes increase of labor 
recourses;

- Regional financial system regulation in terms of local manufacturers' development especially high-technology businesses;

- Formation and development of professional education and employers' interaction on the mutually advantageous basis

- Factors limiting labor production growth:

- Internal competition and regional manufactures' support in the conditions of WTO's entrance

- Strategic development integration economic plans and territory planning;

- Stimulation and system support of labor recourses' professional, territory mobility in accordance with economic situation;

- Active demographic and migration policy focusing on quality and quantity indexes increase of labor recourses;

- Regional financial system regulation in terms of local manufacturers' development especially high-technology businesses;

- Formation and development of professional education and employers' interaction on the mutually advantageous basis

These goals' achievement is possible under the conditions of internal governmental policy, commercial enterprise and social professional associations.

\section{Results}

In conditions of unstable economic situation and possible life standard decrease the research of salary growth and labor production interaction becomes necessary condition to make effective management decisions. This analysis showed the uncertainty of labor market and average salary growth's influence. In the last years we can notice the macroeconomic indexes' significance increase on the average salary growth in comparison with internal enterprises indexes. If we take Samara region as an example we can see how complex actions all round labor production and average salary increase on the macroeconomic level can change the situation considerably. It is justified that system activity on the basis of business and government cooperation in a form of a partnership can influence gradual salary growth. Problematic character of labor production and average salary interaction's issues which cause a lot of opinions about reasons and consequences of researched issues. Data about real and nominal average salary in Samara region show relativity of average salary growth values and purchasing capacity decrease when there is absolute values' increase. During the research definite target indicators were suggested which will allow orienting in the process of solving problems. On the example of Samara region and Russian Federation we see that labor production growth rates' decrease in comparison with average salary growth rates has unfavorable tendencies. On the basis of given data new activity lines for gradual average salary growth. The conclusion about the necessity of business and government parity interaction is made to combine market and non market factors of system labor production and salary growth. To do this possible ways of product and services added value increase are suggested on different conditions of costs formation, and among these factors the main one is labor production growth. Analysis of given factors shows that economic growth, labor production and welfare growth are closely connected with each other and governmental economic policy compliance and effective market subjects' activity. Labor production is under the influence of internal and external processes so in the article main governmental and enterprise influence tendencies were marked.

\section{Conclusion}

Given research show that salary and welfare increase issue is difficult and ambiguous. At present time there is no conclusive opinion about the interaction character of labor production and salary growth. Individual character of each enterprise's internal activity and external conditions of regional economy and management system doesn't allow elaborating unique mechanism of labor production growth and at the same time conceptual approaches to activate processes on which labor production depends can be suggested. It is shown that labor production growth on the regional level will affect life quality and salary greatly. However other possibilities to increase average salary are defined, it depends on other factors including governmental management and budget regulation. Approaches to labor production increase are suggested and on the regional governmental level can be served as a basis fur further research and as a lay out for a complex program of labor production growth on the regional level that will allow activating dynamics of average salary increase and population welfare. 


\section{References}

Aralbaeva G. G., \& Afanasev, V. N. (2007). Labor market and population life quality in Orenburg region. Vestnik of Samara State University of Economics, 3, 16-20.

Beveren, I. V. (2012). Total factor productivity estimation: A practical review. Journal of economic surveys, 26(1), 98-128. http://dx.doi.org/10.1111/j.1467-6419.2010.00631.x

Blanchard, O. J., \& Diamond, P. (1989). The Beveridge curve. Brookings Papers on Economic Activity. http://dx.doi.org/10.2307/2534495

Cappellari, L., Dell'Aringa, C., \& Leonardi, M. (2012). Temporary Employment, Job Flows and Productivity: A Tale of Two Reforms. The Economic Journal, 122(562), 188-215. http://dx.doi.org/10.1111/j.1468-0297.2012.02535.x

Hagedorn, M., \& Manovskii, I. (2011). Productivity and the labor market: Comovement over the business cycle. International Economic Review, 52(3), 603-619. http://dx.doi.org/10.1111/j.1468-2354.2011.00641.x

Jeremy T. F., \& Valérie, S. (2011). Does input quality drive measured differences in firm productivity? International Economic Review, 52(4), 961-989. http://dx.doi.org/10.1111/j.1468-2354.2011.00656.x

Kapelushnikov, R. (2009). Labor production and workforce cost: As ctatistic illusions are born. Economic issues, 4, 59-79.

Klimova, N. V. (2010). Crisis in payment and labor production system on Russian enterprises. Certificate of international Noble economic forum, 1(3), 152-159.

Lentz, R., \& Mortensen, D. T. (2008). An empirical model of growth through product innovation. Econometrica.

Nilova, I. V. (2012). Population life standard and quality: Essence and main indexes (on the example of Ulyanovsk region). National interests: Priorities and security, 2, 58-61.

Pissarides, C. A. (2000). Equilibrium unemployment theory (2nd ed.). Cambridge, London: MIT Press.

Riggi, M. (2010). Nominal and real wage rigidities in new keynesian models: A critical survey. Journal of Economic Surveys, 24(3), 539-572.

Simonova, M. V., \& Grechnikova, S. V. (2014). Labor availability as a factor of efficient use in agricultural production. Human recourses representative, 2, 75-77.

Sorokina, M. S. (2013). Categories relation "prime cost" и "cost" for goals of feature-based added value estimate. Financial accounying, 10, 71-76.

Tyukavkin, N. M. (2008). Salary as economic element. Economic theory magazine, 3, 140-144.

Vasburd, V. A. (2012). Salary organization perfection. Samara State University of Economics, 1, 35-41.

\section{Copyrights}

Copyright for this article is retained by the author(s), with first publication rights granted to the journal.

This is an open-access article distributed under the terms and conditions of the Creative Commons Attribution license (http://creativecommons.org/licenses/by/3.0/). 